Jesus K Yamamoto-Furusho, Dr, Series Editor

\title{
Innate immunity in inflammatory bowel disease
}

\author{
Jesus K Yamamoto-Furusho, Daniel K Podolsky
}

\begin{abstract}
Jesus K Yamamoto-Furusho, Daniel K Podolsky, Gastrointestinal Unit and Center for the Study of Inflammatory Bowel Disease, Massachusetts General Hospital and Harvard Medical School, Boston, MA 02114, United States

Correspondence to: Jesus K Yamamoto-Furusho, MD, PhD, Gastrointestinal Unit, Massachusetts General Hospital, 55 Fruit Street, Boston, Massachusetts 02114,

United States. kazuofurusho@hotmail.com

Telephone: +1-617-7267411 Fax: +1-617-7242136

Received: April 4, 2007 Revised: May 25, 2007
\end{abstract}

\begin{abstract}
The human intestinal tract is home to an enormous bacterial flora. The host defense against microorganisms can be divided into innate and adaptive immunity. The former is the most immediate line of response to immunologic challenges presented by bacteria, viruses, and fungi. The mucosal immune system has evolved to balance the need to respond to pathogens while co-existing with commensal bacteria and food antigens. In inflammatory bowel disease (IBD), this hyporesponsiveness or tolerance breaks down and inflammation supervenes driven by the intestinal microbial flora. Bacteria contain compounds and are recognized by a variety of receptors, including Toll-like receptors (TLRs) and NODs (a family of intracellular bacterial sensors) and are potent stimuli of innate immune responses. Several mutations in these receptors have been associated with development of IBD.
\end{abstract}

\section{(c) 2007 WJG. All rights reserved.}

Key words: Innate; Immunity; Toll-like receptors; Inflammatory bowel disease

Yamamoto-Furusho JK, Podolsky DK. Innate immunity in inflammatory bowel disease. World J Gastroenterol 2007; 13(42): 5577-5580

http://www.wjgnet.com/1007-9327/13/5577.asp

\section{INTRODUCTION}

Inflammatory bowel disease (IBD) comprises two major forms of chronic inflammation of the intestine, Crohn's disease (CD) and ulcerative colitis (UC).

IBD is currently presumed to result from the complex effect of diverse genes conferring risk of disease and environmental factors, which when combined lead to an aberrant inflammation response. Recent evidence suggests that innate immune responses play an important role in initiating the inflammatory cascade and subsequent characteristic pathological adaptive immune responses ${ }^{[1]}$. The innate immune response is the first line of defense for microbial infections. In addition to genetic factors in IBD, numerous studies have implicated a key role of the intestinal microbiota in patients with $\mathrm{IBD}^{[2-4]}$. The contribution of luminal microbes to the pathogenesis of IBD is highlighted by reports that surgical diversion of the fecal stream effectively resolves CD inflammation distal to the surgical site ${ }^{[2]}$.

The human intestinal tract mucosa is exposed to an enormous microbial flora. A single layer of epithelial cells separates the host tissues from luminal bacteria. Innate immune mechanisms are involved in this relationship, and likely contribute significantly to the protection of the host from invasion by luminal bacteria and provide a rapid response to pathogens. Immediate activation of innate immunity relies on the detection by the host of conserved microbial motifs known as pathogen-associated molecular patterns (PAMPs), comprising diverse molecules from bacteria and viruses such as lipopolysaccharide, peptidoglycan, flagellin and lipoproteins ${ }^{[5]}$.

Understanding of innate immunity has accelerated enormously with the discovery of many microbial sensors called "pattern recognition receptors" (PRRs). The tolllike receptor (TLR) and NOD receptor families of PRRs appear to play essential roles in mucosal homeostasis and alterations contribute to the pathogenesis of IBD.

\section{THE TLR FAMILY}

The mammalian TLR family consists of 13 mammalian members: each TLR having its intrinsic signaling pathway and inducing specific biological responses against microorganisms. Recognition of microbial components by TLRs triggers activation of signal transduction pathways, which then induce dendritic cell maturation and cytokine production, resulting in development of adaptive immunity ${ }^{[5]}$.

Table 1 summarizes TLRs and the different molecular patterns associated with a broad range of microbes that they recognize. The activation of TLR signaling pathways originates from the cytoplasmic TIR domains. Four TIR domain-containing adaptors (MyD88, TIRAP/MAL, TRIF, and TRAM) play an important role in TLR signaling 
Table 1 Molecular pattern recognition of NODs and TLRs

\begin{tabular}{ll}
\hline Receptor & Microbial motifs \\
\hline NLR family & \\
NOD1 & $\begin{array}{l}\text { Lanthionine meso-diaminopimelic acid (meso-DAP) } \\
\text { r-D-Glu-meso-diaminopimelic acid (iE-DAP) }\end{array}$ \\
NOD2 & Muramyldipeptide (MDP) \\
TLR family & \\
TLR1 & Triacyl lipopeptides \\
TLR2 & Lipoprotein, lipopeptides (Pam3CysSerLys4) \\
TLR3 & dsRNA \\
TLR4 & LPS \\
TLR5 & Flagellin \\
TLR6 & Diacyl lipopeptides \\
TLR7/TLR8 & ssRNA \\
TLR9 & Non-methylated CpG DNA \\
TLR11 & Component of uropathogenic bacteria \\
\hline
\end{tabular}

pathway. These adaptors are associated with TLRs through homophilic interaction of TIR domains. Each TLR mediates distinctive responses in association with a different combination of these adapters ${ }^{[6]}$.

\section{THE NLR FAMILY}

The mammalian NLR family comprises more than 20 members whose defining molecular characteristic is a C-terminal leucine-rich repeat (LRR) domain, a central nucleotide-binding NACHT domain and an N-terminal protein-protein interaction domain composed of a CARD (caspase activation and recruitment domain). Several studies have shown that several NLRs are necessary sensors of specific PAMPs.

The first NLRs reported to have a direct function as intracellular PRRs were NOD1 (CARD4) and NOD2 (CARD15). NOD2 detects muramyl dipeptide, the largest molecular motif common to Gram-negative and Grampositive bacteria ${ }^{[7,8]}$. In contrast, NOD1 senses peptidoglycan containing meso-diaminopimelic acid (meso-DAP), which is more commonly found in Gram-negative bacteria ${ }^{[1,10]}$.

NALP3 is a pyrin domain-containing NLR that activates the caspase-1 leading to interleukin $1 \beta$ (IL-1 $\beta$ ) and IL-18 processing, this protein is involved in sensing microbial components. In addition to NODs and NALP3 proteins, Ipaf (CARD12) and Nalp1 are intracellular sensors that detect intracellular flagellin, leading to inflammasome activation through a TLR5-independent pathway $^{[11]}$.

The signaling pathways downstream of NLRs include the $\mathrm{NF}_{-} \kappa \mathrm{B}$ pathway, for NOD1 and NOD2, and activation of the caspase 1 inflammasome, for NAPLPs, Ipaf and Naip. NOD1 and NOD2 rapidly form oligomers and then transiently recruit receptor-interacting protein 2 (RIP2) through CARD-CARD interactions. The complex NODRIP2 then recruits the inhibitor of $\mathrm{NF}-\kappa \mathrm{B}$ kinase complex, which leads to activation of $\mathrm{NF}_{-} \kappa \mathrm{B}$. Several studies have shown that Ipaf and Naip can participate in the formation of inflammasomes (NALP1, NALP3 and Ipaf) that form in response to the detection of specific molecular motifs. It has been speculated that the formation of large protein complexes in a given inflammasome is sufficient to trigger caspase-1 activation ${ }^{[12]}$.
NLRs are important in macrophage-mediated detection and control of bacterial infection in vitro. Ipaf is required for caspase- 1 activation and IL- $1 \beta$ secretion in macrophages exposed to Gram-negative pathogen Salmonella typhimurium ${ }^{[13]}$. Cytosolic recognition of Salmonella typhimurium and Legionella pneumophila flagellins by Ipaf results in the induction of macrophage cell death and IL$1 \beta$ secretion.

\section{CONNECTION OF NOD AND TLR PATHWAYS}

Intersection between TLR and NOD2 pathways is suggested by reports of synergistic induction of proinflammatory cytokines such as TNF $\alpha$ and IL- $1 \beta$ upon costimulation with MDP and specific TLR ligands ${ }^{[14,15]}$. MDP also substantially upregulated secretion of $\mathrm{TNF}_{\alpha}$ and IL-1 $\beta$ induced by ligands to five different TLRs ligands, TLRs 2, 4, 5, 7 and 9: (Pam ${ }_{3} \mathrm{CysSerLys}_{4}$, LPS, Flagellin, MALP-2 and R-848, respectively). Of note, these effects were observed in the presence of the most common NOD2 mutants associated with CD. In studies using mice lacking NOD2, Watanabe et al observed reduced responses to MDP, but enhanced responses to the TLR2 ligand peptidoglycan e.g., increases in IL-12. They interpreted these findings to suggest that the NOD2 signaling pathways normally down-regulate the TLR2 pathways. In their model, loss of function mutation of NOD2 together with TLR2 signals delivered by other bacterial products could result in enhanced cytokine responses to commensal bacteria by macrophages ${ }^{[16]}$. These findings suggest that interaction between NOD2 and specific TLR pathways may represent an important modulatory mechanism of innate immune responses, which is altered in some patients with CD.

\section{TLRS IN IBD}

TLRs are abundantly expressed on the surface of monocytes, macrophages, dendritic and epithelial cells. Alterations of TLR3 and TLR4 expression by intestinal epithelial cells have been described in $\operatorname{IBD}^{[17]}$, suggesting that there is differential expression of TLR family members. Thus, primary intestinal epithelial cells of normal, non-diseased mucosa constitutively express TLR3 and TLR5, whereas TLR2 and TLR4 are present in much lower amounts. In active IBD, the expression of TLR3 and TLR4 was differentially modulated in the intestinal epithelium. TLR3 was significantly down-regulated in active CD but not in UC. In contrast, TLR4 was strongly up-regulated in both UC and CD. TLR 2 and TLR5 expression remained unchanged in IBD.

Two common polymorphisms of TLR4 (Asp299Gly and Thr399Ile) have been described in humans. Asp299Gly has been associated with reduced responsiveness following lipopolysaccharide stimulation ${ }^{[18]}$. These polymorphisms have been associated with the development of CD and UC in Caucasian populations ${ }^{[19-21]}$.

Recently, Pierik et al ${ }^{[2]}$ showed that TLR1 R80T and TLR2 R753G polymorphisms were associated with pancolitis in UC patients, while a negative association 
was observed between TLR6 S249P and proctitis in patients with UC. These results suggest that TLR2 and its co-receptors TLR1 and TLR6 are involved in the initial immune response to bacteria in the pathogenesis of IBD.

An important immune stimulatory effect mediated by the TLR family (TLR9) is induced by non-methylated CpG motifs found in bacterial DNA. In animal models of colitis, administration of $\mathrm{CpG}$ was able to ameliorate disease activity ${ }^{[23]}$.

\section{NODS IN IBD}

Specific mutations of the NOD2 gene have been definitively associated with increased susceptibility to ileal Crohn's disease in Western (but not Asian) populations: Arg702Trp, Gly908Arg, and leu1007fsinsC (a frameshift mutation that truncates the carboxy terminal 33 amino acids) ${ }^{[24,25]}$. Heterozygous carriage of the risk alleles confers a 2-4 fold increased risk, and homozygotes or compound heterozygotes have a 20-40 fold increased risk ${ }^{[2]}$. More than $90 \%$ of all CD associated mutations are located in the LRR domain, suggesting that these may affect the function of NOD2 with respect to bacterial recognition and signaling. Transient transfection experiments indicate that $\mathrm{CD}$-associated NOD2 mutants no longer activate NF- $\mathrm{B}$ in response to $\mathrm{MDP}^{[27,28]}$, which suggests that defective $\mathrm{NF}-\kappa \mathrm{B}$ activation facilitates infection of the lamina propria by enteric bacteria.

NOD2 mutants produce selective functional defects in leukocytes of patients with CD as shown by van Heel et $a l^{[8]}$ who analyzed cytokine expression of peripheral blood mononuclear cells after exposure to MDP. In PBMC from $\mathrm{CD}$ patients the NOD2 ligand induced little TNF $\alpha$ and IL-1 $\beta$, but strong IL-8 secretion. Furthermore, monocytes isolated from CD patients carrying the 1007fs (3020insC) mutation were reported to exhibit defects in the production of the proinflammatory cytokines, TNF $\alpha$, IL- 6 and IL-8, as well as the anti-inflammatory cytokine IL- $10^{[22]}$. Dendritic cells derived from CD patients homozygous for leu1007fsinsC also fail to up-regulate the costimulatory molecules CD80 and CD86 in response to MDP and lack production of cytokines such as TNF- $\alpha$, IL-12 and IL- $10^{[30]}$.

Evidence that NOD2 functions as an antibacterial factor in intestinal epithelial cells was demonstrated in Caco-2 cells stably expressing wild type NOD2 when infected with Salmonella typhimurium. This protective effect was absent in cells expressing a most common mutant NOD2 associated with $\mathrm{CD}$ (3020insC) $)^{[31]}$.

NOD2 mutations in CD patients are also associated with diminished mucosal $\alpha$-defensin expression ${ }^{[32]}$. Decreased $\beta$-defensin 1 and the lack of induction of both inducible antimicrobial peptides $\beta$-defensins 2 and 3 in CD could result in enhanced bacterial invasion and perhaps survival $^{[33]}$.

A study of 556 patients with IBD (294 CD and 252 UC) reported an association between the variant (rs695857) in nucleotides 30, 258 and 950 of the NOD1 gene and the development of IBD. Another variant known as rs 2907748 in nucleotides 30, 246 and 263 was also associated with the presence of $\mathrm{UC}$ and $\mathrm{CD}$, particularly early onset of the disease $(<25 \text { years })^{[34]}$.

\section{CROHN 'S DISEASE}

Marks et al ${ }^{[35]}$ have provided provocative evidence that CD patients possess a generalized impaired innate immune response as reflected by diminished response to intradermal injection of killed bacteria as well as trauma of the skin or the intestine. When killed bacteria were injected into the forearms of CD patients, there was less blood flow to the injection site than non-CD patients. They also found that CD patients had reduced neutrophil accumulation and interleukin-8 (IL-8) production at sites of tissue trauma in the intestine and skin, although these findings need corroboration. This study supports the idea that CD may in some way be associated with relative inability to mount an acute inflammatory response compared to normal individuals.

Recent studies have suggested that the CD-associated NOD2 mutants might confer a milder defect in innate immune response than well-described innate immune deficiencies such as chronic granulomatous disease ${ }^{[8]}$. Rather than suppressing the secondary T-cell response, a different approach aims to normalize innate immune function through qualitative augmentation of neutrophil, macrophage and dendritic cell function. Clinical trials of granulocyte colony stimulating factor (G-CSF, specifically filgrastim) and GM-CSF (sargramostim) have suggested a benefit, although definitive evidence is not yet available ${ }^{[36,37]}$. However, G-CSF has a more limited effect on the innate immune system, acting primarily on neutrophils. GM-CSF is more widely and potently active, targeting a variety of cell types including not only neutrophils and monocytes as effector cells, but also intestinal epithelial cells that have receptors for GM-CSF.

\section{CONCLUSION}

The innate immune system is the first line of defense and provides a rapid response to pathogens. Elicitation of an innate immune response to bacterial products is mediated through families of pattern recognition receptors including the cell surface TLRs and cytosolic NODs that mediate the activation of $\mathrm{NF}_{-\kappa} \mathrm{B}$. Some mutations, TLRs, and NODs produce defects in sensing of pathogens and predispose the host to recurrent infections as well as perpetuation of chronic intestinal inflammation.

\section{REFERENCES}

1 Podolsky DK. Inflammatory bowel disease. N Engl J Med 2002; 347: 417-429

2 Rutgeerts P, Goboes K, Peeters M, Hiele M, Penninckx F, Aerts R, Kerremans R, Vantrappen G. Effect of faecal stream diversion on recurrence of Crohn's disease in the neoterminal ileum. Lancet 1991; 338: 771-774

3 Darfeuille-Michaud A, Boudeau J, Bulois P, Neut C, Glasser AL, Barnich N, Bringer MA, Swidsinski A, Beaugerie L, Colombel JF. High prevalence of adherent-invasive Escherichia coli associated with ileal mucosa in Crohn's disease. Gastroenterology 2004; 127: 412-421

4 Sartor RB. Therapeutic manipulation of the enteric microflora in inflammatory bowel diseases: antibiotics, probiotics, and prebiotics. Gastroenterology 2004; 126: 1620-1633

5 Akira S, Uematsu S, Takeuchi O. Pathogen recognition and innate immunity. Cell 2006; 124: 783-801 
6 Uematsu S, Akira S. Toll-like receptors and innate immunity. J Mol Med (Berl) 2006; 84: 712-725

7 Girardin SE, Boneca IG, Viala J, Chamaillard M, Labigne A, Thomas G, Philpott DJ, Sansonetti PJ. Nod2 is a general sensor of peptidoglycan through muramyl dipeptide (MDP) detection. J Biol Chem 2003; 278: 8869-8872

8 van Heel DA, Ghosh S, Butler M, Hunt KA, Lundberg AM, Ahmad T, McGovern DP, Onnie C, Negoro K, Goldthorpe S, Foxwell BM, Mathew CG, Forbes A, Jewell DP, Playford RJ. Muramyl dipeptide and toll-like receptor sensitivity in NOD2associated Crohn's disease. Lancet 2005; 365: 1794-1796

9 Hisamatsu T, Suzuki M, Podolsky DK. Interferon-gamma augments CARD4/NOD1 gene and protein expression through interferon regulatory factor- 1 in intestinal epithelial cells. J Biol Chem 2003; 278: 32962-32968

10 Girardin SE, Boneca IG, Carneiro LA, Antignac A, Jéhanno M, Viala J, Tedin K, Taha MK, Labigne A, Zähringer U, Coyle AJ, DiStefano PS, Bertin J, Sansonetti PJ, Philpott DJ. Nod1 detects a unique muropeptide from gram-negative bacterial peptidoglycan. Science 2003; 300: 1584-1587

11 Franchi L, Amer A, Body-Malapel M, Kanneganti TD, Ozören N, Jagirdar R, Inohara N, Vandenabeele P, Bertin J, Coyle A, Grant EP, Núñez G. Cytosolic flagellin requires Ipaf for activation of caspase- 1 and interleukin 1beta in salmonellainfected macrophages. Nat Immunol 2006; 7: 576-582

12 Martinon F, Tschopp J. Inflammatory caspases: linking an intracellular innate immune system to autoinflammatory diseases. Cell 2004; 117: 561-574

13 Miao EA, Alpuche-Aranda CM, Dors M, Clark AE, Bader MW, Miller SI, Aderem A. Cytoplasmic flagellin activates caspase-1 and secretion of interleukin 1beta via Ipaf. Nat Immunol 2006; 7: 569-575

14 Strober W, Murray PJ, Kitani A, Watanabe T. Signalling pathways and molecular interactions of NOD1 and NOD2. Nat Rev Immunol 2006; 6: 9-20

15 Netea MG, Kullberg BJ, de Jong DJ, Franke B, Sprong T, Naber TH, Drenth JP, Van der Meer JW. NOD2 mediates antiinflammatory signals induced by TLR2 ligands: implications for Crohn's disease. Eur J Immunol 2004; 34: 2052-2059

16 Watanabe T, Kitani A, Murray PJ, Strober W. NOD2 is a negative regulator of Toll-like receptor 2-mediated $\mathrm{T}$ helper type 1 responses. Nat Immunol 2004; 5: 800-808

17 Cario E, Podolsky DK. Differential alteration in intestinal epithelial cell expression of toll-like receptor 3 (TLR3) and TLR4 in inflammatory bowel disease. Infect Immun 2000; 68: 7010-7017

18 Arbour NC, Lorenz E, Schutte BC, Zabner J, Kline JN, Jones M, Frees K, Watt JL, Schwartz DA. TLR4 mutations are associated with endotoxin hyporesponsiveness in humans. Nat Genet 2000; 25: 187-191

19 Franchimont D, Vermeire S, El Housni H, Pierik M, Van Steen K, Gustot T, Quertinmont E, Abramowicz M, Van Gossum A, Devière J, Rutgeerts P. Deficient host-bacteria interactions in inflammatory bowel disease? The toll-like receptor (TLR)-4 Asp299gly polymorphism is associated with Crohn's disease and ulcerative colitis. Gut 2004; 53: 987-992

20 Arnott ID, Ho GT, Nimmo ER, Satsangi J. Toll-like receptor 4 gene in IBD: further evidence for genetic heterogeneity in Europe. Gut 2005; 54: 308; author reply 309

21 Lakatos PL, Lakatos L, Szalay F, Willheim-Polli C, Osterreicher C, Tulassay Z, Molnar T, Reinisch W, Papp J, Mozsik G, Ferenci P. Toll-like receptor 4 and NOD2/CARD15 mutations in Hungarian patients with Crohn's disease: phenotypegenotype correlations. World J Gastroenterol 2005; 11: 1489-1495

22 Pierik M, Joossens S, Van Steen K, Van Schuerbeek N, Vlietinck R, Rutgeerts P, Vermeire S. Toll-like receptor-1, -2 , and -6 polymorphisms influence disease extension in inflammatory bowel diseases. Inflamm Bowel Dis 2006; 12: 1-8

23 Rachmilewitz D, Katakura K, Karmeli F, Hayashi T, Reinus C, Rudensky B, Akira S, Takeda K, Lee J, Takabayashi K,
Raz E. Toll-like receptor 9 signaling mediates the antiinflammatory effects of probiotics in murine experimental colitis. Gastroenterology 2004; 126: 520-528

24 Ogura Y, Bonen DK, Inohara N, Nicolae DL, Chen FF, Ramos R, Britton H, Moran T, Karaliuskas R, Duerr RH, Achkar JP, Brant SR, Bayless TM, Kirschner BS, Hanauer SB, Nunez G, Cho JH. A frameshift mutation in NOD2 associated with susceptibility to Crohn's disease. Nature 2001; 411: 603-606

25 Hugot JP, Chamaillard M, Zouali H, Lesage S, Cézard JP, Belaiche J, Almer S, Tysk C, O'Morain CA, Gassull M, Binder V, Finkel Y, Cortot A, Modigliani R, Laurent-Puig P, GowerRousseau C, Macry J, Colombel JF, Sahbatou M, Thomas G. Association of NOD2 leucine-rich repeat variants with susceptibility to Crohn's disease. Nature 2001; 411: 599-603

26 Cuthbert AP, Fisher SA, Mirza MM, King K, Hampe J, Croucher PJ, Mascheretti S, Sanderson J, Forbes A, Mansfield J, Schreiber S, Lewis CM, Mathew CG. The contribution of NOD2 gene mutations to the risk and site of disease in inflammatory bowel disease. Gastroenterology 2002; 122: 867-874

27 Inohara N, Ogura Y, Fontalba A, Gutierrez O, Pons F, Crespo J, Fukase K, Inamura S, Kusumoto S, Hashimoto M, Foster SJ, Moran AP, Fernandez-Luna JL, Nuñez G. Host recognition of bacterial muramyl dipeptide mediated through NOD2. Implications for Crohn's disease. J Biol Chem 2003; 278: 5509-5512

28 Girardin SE, Travassos LH, Hervé M, Blanot D, Boneca IG, Philpott DJ, Sansonetti PJ, Mengin-Lecreulx D. Peptidoglycan molecular requirements allowing detection by Nod1 and Nod2. J Biol Chem 2003; 278: 41702-41708

29 van Heel DA, Ghosh S, Butler M, Hunt KA, Lundberg AM, Ahmad T, McGovern DP, Onnie C, Negoro K, Goldthorpe S, Foxwell BM, Mathew CG, Forbes A, Jewell DP, Playford RJ. Muramyl dipeptide and toll-like receptor sensitivity in NOD2associated Crohn's disease. Lancet 2005; 365: 1794-1796

30 Netea MG, Ferwerda G, de Jong DJ, Jansen T, Jacobs L, Kramer M, Naber TH, Drenth JP, Girardin SE, Kullberg BJ, Adema GJ, Van der Meer JW. Nucleotide-binding oligomerization domain-2 modulates specific TLR pathways for the induction of cytokine release. J Immunol 2005; 174: 6518-6523

31 Kramer M, Netea MG, de Jong DJ, Kullberg BJ, Adema GJ. Impaired dendritic cell function in Crohn's disease patients with NOD2 3020insC mutation. J Leukoc Biol 2006; 79: 860-866

32 Hisamatsu T, Suzuki M, Reinecker HC, Nadeau WJ, McCormick BA, Podolsky DK. CARD15/NOD2 functions as an antibacterial factor in human intestinal epithelial cells. Gastroenterology 2003; 124: 993-1000

33 Wehkamp J, Harder J, Weichenthal $\mathrm{M}$, Schwab M, Schäffeler E, Schlee M, Herrlinger KR, Stallmach A, Noack F, Fritz P, Schröder JM, Bevins CL, Fellermann K, Stange EF. NOD2 (CARD15) mutations in Crohn's disease are associated with diminished mucosal alpha-defensin expression. Gut 2004; 53: 1658-1664

34 Fellermann K, Wehkamp J, Herrlinger KR, Stange EF. Crohn's disease: a defensin deficiency syndrome? Eur J Gastroenterol Hepatol 2003; 15: 627-634

35 McGovern DP, Hysi P, Ahmad T, van Heel DA, Moffatt MF, Carey A, Cookson WO, Jewell DP. Association between a complex insertion/deletion polymorphism in NOD1 (CARD4) and susceptibility to inflammatory bowel disease. Hum Mol Genet 2005; 14: 1245-1250

36 Marks DJ, Harbord MW, MacAllister R, Rahman FZ, Young J, Al-Lazikani B, Lees W, Novelli M, Bloom S, Segal AW. Defective acute inflammation in Crohn's disease: a clinical investigation. Lancet 2006; 367: 668-678

37 Dieckgraefe BK, Korzenik JR. Treatment of active Crohn's disease with recombinant human granulocyte-macrophage colony-stimulating factor. Lancet 2002; 360: 1478-1480

38 Korzenik JR, Dieckgraefe BK. An open-labelled study of granulocyte colony-stimulating factor in the treatment of active Crohn's disease. Aliment Pharmacol Ther 2005; 21: 391-400 